\title{
The Urgency of Regulating Fintech Peer to Peer Lending Sharia in Indonesia
}

\author{
Otih Handayani ${ }^{1}$, Adi Sulistiyono ${ }^{2}$, Yudho Taruno Muryanto ${ }^{3}$ \\ 1. Universitas Bhayangkara, Jakarta, Indonesia \\ ${ }^{2.3}$ Universitas Sebelas Maret, Surakarta, Indonesia \\ otih.handayani@gmail.com
}

\begin{abstract}
This reserch aims to analyze the urgency of Fintech Peer to Peer Lending (P2P Lending) Sharia law in Indonesian Muslim communities. This research is normative legal research that is authoritative and technical/applied. The research approach uses the law approach. The licensed material of this research uses primary and secondary legal materials. The technique of collecting legal materials through library research or document research (library research), then analyzed using qualitative methods. The results of this research are applying the theory of utilitarian and sharia principles in the legal arrangement of Fintech P2P Lending Sharia is expected to meet the Indonesian Muslim community's sense of security in choosing the best alternative for P2P Lending financial services. although the parties feel safe, the Fatwa as the legal basis for the implementation of sharia P2P fintech does not have a position in a positive source of Indonesian law so that it is not binding; and to be valid and binding, the fatwa must be regulated in a statutory regulation.
\end{abstract}

Keywords- Peer to Peer Lending Sharia, utilitarian, regulation.

\section{INTRODUCTION}

The 4.0 industrial revolution has now become a matter of almost all parts of the world. Includes various industries, including transportation, retail sales, finance, agriculture, insurance, health, etc. In the service sector, technology-based innovations such as finance or financial Technology (Fintech) have penetrated various areas, such as startup payments, lending, financial planning (personal finance), retail investment, financing (crowdfunding), electronic money, and others are expected to build an inclusive economy.

The third National Survey of Financial Literacy and Inclusion (SNLIK) conducted by the Financial Services Authority (OJK) in 2019 showed the financial literacy index reached $38.03 \%$ and the financial inclusion index $76.19 \%$. This figure increased compared to the results of the OJK 2016 survey, namely the financial literacy index of $29.7 \%$ and the financial inclusion index of $67.8 \%$ [1].

Fintech products that are currently widely used are peer-to-peer lending (P2P lending). P2P Lending seeks to solve lending to Small and Medium businesses (SMEs) by utilizing automated processes to reduce costs and credit risk models using nontraditional data. Fintech has grown rapidly over the last few years but has risen. P2P lending is the largest component, the People's Republic of China (PRC), and the US is the largest market globally, with $\$ 100$ billion new Fintech credits issued in the PRC in 2015 and \$34 billion in the US. Credit volume Fintech $\$ 1.1$ billion in Asia and the Pacific does not include the PRC and less than \$1 billion in the eurozone (Bank for International Settlements 2017). Loans to individuals are the largest P2P lending in the PRC, and the US P2P Lending for business is still relatively small but has grown rapidly [2].

In $2010,23 \%$ or 1.6 billion of the world's population were Muslim, making Islam the second largest religion in the world. The number of Muslims worldwide is projected to increase rapidly in the coming decades, growing to nearly 2.8 billion by 2050 . The Asia-Pacific region is expected to remain home to the world's Muslim majority i.e. living in several countries. Asia with large Muslim populations such as Indonesia, India and Pakistan [3].

The latest report from the global news platform Salam Gateway shows Indonesia is the fifth largest Islamic financial technology market globally. Global Fintech Islamic Report 2021 from Salam Gateway recorded the first rank of Saudi Arabia US\$ 17.9 billion, Then Iran US \$ 9.2 billion, United Arab Emirates US \$ 3.7 billion, Malaysia US \$ 3 billion, and the Indonesian sharia fintech market US \$ 2.9 billion or Rp 41.7 trillion. Millennials drive the growth of sharia fintech. Islamic financing scheme enthusiasts in Indonesia are quite large; the State of The Global Islamic Economic Report recorded the consumption and export of Indonesian halal products increased by $3.6 \%$ and $19.2 \%$, respectively, in 2017. Sharia financial assets reached US\$ 82 billion or around $\mathrm{Rp} 1,155$ trillion. Moreover, digitalization is getting massive during the corona pandemic, including financial services. This makes the potential of sharia fintech even greater [4].

As the largest Muslim country globally, based on global religious future data, the Muslim population of Indonesia in 2010 reaches 209.12 million people, or about $87 \%$ of the total population. Later in 2020 , Indonesian Muslims are expected to reach 229.62 million people [5]. This remarkable market potential makes Indonesia a fertile farm for sharia P2P Lending fintech growth, where the financial services are also growing rapidly in Malaysia and Singapore. Thomson Reuters estimates that the world's Sharia financial markets will reach 3.8 trillion US dollars in 2022 [6].

The presence of sharia fintech peer-to-peer lending offers an alternative for borrowers and investors who are interested in Islamic values. Sharia fintech peer-to-peer lending has the potential to be developed in Indonesia. 
The app is in line with technological advances and Islamic values, namely a ban on interest, transparency, and a sophisticated credit scoring system, allowing residents who do not have bank accounts to access financial services, especially loans [7]. The factor that distinguishes ordinary FinTech from Islam is the need to adhere to Shariah principles. By combining safe investment, social responsibility, innovation, and efficiency using available tools, Islamic Finance can be used as a modern and effective financial instrument [8].

The Government of Indonesia has inaugurated the Master Plan of Sharia Economic Indonesia (MEKSI) 2019-2024 as a roadmap for sharia economic development in Indonesia to encourage national economic growth. The goal is for the growth of the Islamic financial sector to have a direct and significant impact on growth in the real sector, which is fundamentally the main focus in the Islamic economic system [9].

P2P Lending is only governed by regulation of the Financial Services Authority no. 77/POJK.01/2016 on Money Lending services based on information technology, as for P2P Lending Sharia, which has a specificity to tether the regulation of the National Sharia Council of Ulama Indonesia No. 117/2018 on information technology-based financing services based on sharia principles whose legal force is not binding.

Based on the background above, the problem raised in this writing is how fintech $p 2 p$ lending sharia financial services carry out money lending services based on information technology with Sharia principles? Furthermore, How is the urgency of regulation of Fintech $P 2 P$ Lending Syariah in meeting the legal objectives of benefits for the parties in Fintech P2P Lending Syariah?

State of the art research is taken from several examples of previous research in the form of journals, including research entitled The Fintech And Islamic Finance Synthesis In The Modern World by Bulatova, E.I., Potapova, E.A., Fathutdinova, R.A., \&Yandiev, R.C. published by 3C TIC Cuadernos de desarrollo aplicados a las TIC in October 2019 DOI: https://doi. org/10.17993/3ctic.2019.83-2.258-273. This article discusses the economic prerequisites for effective Islamic Financial growth in current conditions, analyzing Islamic finance, banking, and financial technology definitions. The research results are that FinTech is currently gaining momentum in areas such as online lending, money transfer, crowdfunding, blockchain, and cryptocurrency. The usual FinTech distinguishes from Islam is the need to adhere to Sharia principles that combine safe investment, social responsibility, innovation, and efficiency [8]. The research entitled Legal Protection of Consumers Users of Financial Technology Based on Peer To Peer Lending Sharia In Indonesia by Delfa Violina, Renny Supriyatni, Djanuard published by Adjudication: Jurnal Ilmu Hukum Volume 5 Number 1 the Year 2021 https://doi.org/10.30656/ajudikasi.v5i1.3267, the result of this study is that Fintech Peer to Peer Lending Syariah must follow sharia principles based on the rules set by the Financial Services Authority and Fatwa of the Indonesian
Ulema Council, the ease provided by Fintech Peer to Peer Lending Syariah has the possibility for all risks that exist therefore it is expected that the Government can protect all parties with comprehensive regulations.

The theory of law or legal principle that became the theoretical framework in this study is the Theory of Benefit and Sharia Principles. The theory of utilitarianism was initiated by Jeremy Bentham and supported by other figures such as John Stuart Mill and Rudolf von Jhering. Bentham asserts that the Government's goal and the purpose of the law must be "community greatest happiness" or "community happiness" or "The Greatest Happiness of The Greatest Number." [10]. The Sharia Principle as an analysis knife in this study is the principle of Islamic law governed by the Fatwa of the Indonesian Ulema Council such as the principle of justice and balance ('adl was tawazun), fairness and does not contain gharar, maysir, riba, tadlis, dharar, zhulm, and haram[11].

\section{RESEARCH METHOD}

This research is a type of normative law research that is prescriptive with a statue approach. The types and sources of data used are the primary legal materials obtained from the Constitution of the Republic of Indonesia in 1945, Law No. 21 of 2011 on Financial Services Authority, Law No. 12 of 2011 on the Establishment of Laws and Regulations related to the author's research. Secondary legal materials are obtained from experts' books, literature, official documents, scientific works, and legal journals. The data in this study were analyzed using qualitative methods.

\section{FINDING AND DISCUSSION}

1. The Law Meets the Interests of Individuals and Society Law has a very important role in economic life due to its ability to influence the level of certainty in the relationship between people in society [12]. Each individual in community life has different interests, in which each desires to fulfill as many of these interests as possible [13]. The rise of Fintech P2P Lending as a 4.0 industrial product today as a breakthrough financial services business that leaves rigidly conventional financial services has an impact on the high utilization of these services that require legal arrangements to ensure the fulfillment of the rights and obligations of the parties who can eventually fulfill the legal ideals of which benefit. One of the intended interests is the sense of security in this business that can be a source of happiness.

In Indonesia, As of June 2021, the OJK records P2P Lending users amounting to 64 million accounts. In contrast, the amount of credit that has been channeled reached $\mathrm{Rp} 221.56$ trillion [14]. OJK data mentions that until June 2021, 124 Fintech P2P Lending are operating legally in Indonesia, both conventional and sharia P2P lending [15].

The Indonesian Sharia Fintech Association (AFSI) was initiated in October 2017 or Muharram / Safar 1439 
in Jakarta by the Tazkia Sharia Fintech Study Center and 8 Sharia Fintech Startups in Jakarta. AFSI was officially established on February 8, 2018. AFSI's vision is to become a forum for realizing economic equity and justice, as well as accelerating the development of the sharia economy through financial technology innovation for the benefit of all Indonesian people.

AFSI has been recognized and ratified as a legal entity, through the Decree of the Minister of Law and Human Rights of the Republic of Indonesia Number AHU-0001911.AH.01.07 of 2018 dated February 14, 2018 [16]. As of August 2021, a total of 9 sharia peer-topeer lending fintechs [17] registered with the OJK, seven of which are members of AFSI (Alami Technology Syariah (Alami), Ammana Fintech Syariah (Ammana), PT Dana Syariah Indonesia (Danasyariah. Id), PT Ethis Fintek Indonesia (Ethis Indonesia), PT Kapital Boost Indonesia (Kapital Boost), PT Berkah Finteck Syariah (PT Berkah Finteck Syariah), PT Synergy Core Berkah Investama (Goolive)) [18].

The current regulation of Fintech P2P Lending is based on the Financial Services Authority Regulations (POJK) Number 77/POJK.01/2016 on money-lending services based on information technology that regulates both conventional $\mathrm{P} 2 \mathrm{P}$ lending fintech and the fintech P2P lending Shariah. According to fiqh, some Islamic scholars say that "something that applies based on Adat is the same as something that applies based on sharia as long as it is not contrary to sharia."[7].

Allah says in the Qur'an Surah Al Nisa Verse 29: "O you who have believed! Do not consume the property of others in vain unless it is a voluntary trade between you. " ... this paragraph is one of the references to the issuance of the Fatwa of the National Sharia Council of the Indonesian Ulema Council (DSN MUI) Number 117/DSN-MUI/II/2018 on Information TechnologyBased Financing Services based on Sharia Principles dated February 22, 2018. This Fatwa is the basic rule of implementation of Sharia Fintech $P 2 P$ Lending. Things to note from OJK. Regulation No. 77 /POJK.01/2016 and Fatwa of the National Sharia Council of the Indonesian Ulema Council (DSN MUI) Number 117/DSN-MUI/II/2018 are as follows:

1) POJK Article 19 states that (1) the agreement on the service of lending borrowed money-based information technology between the organizers and lenders is poured out in electronic documents; (2) electronic documents as referred to in paragraph (1) shall at least contain: a. Agreement number; b. date of the agreement; c. identity of the parties; $d$. provisions on the rights and obligation, the parties; e. loan amount; f. interest rate of loans; g. the amount of commission; h. timeframe; i. related fee details; j. Provisions on fines (if any); $\mathrm{k}$. dispute resolution mechanisms; and 1. mechanism of completion if the organizer cannot continue its operational activities.

2) Fatwa of MUI on the fourth decision (1) stated that Sharia fintech business activities should not contradict the principle of sharia, which is among others spared from Riba, Gharar (obscurity of Akad), maysir (uncertainty of purpose/speculation), Tadlis (not transparent), Dhara (Danger), Zhulm (loss of one party), and haram The understanding of Riba according to the first decision figure (18) is the addition given in the exchange of Ribawi goods (riba Fadl) or the additional promised on the subject of the debt in exchange for the suspension of full payment (Riba Nasi'ah) [11].

The most striking differences between the two are seen among others in the application of interest or usury. Generally, sharia fintech does not charge interest on borrowers, so transactions between investors, sharia fintech companies, and borrowers are cooperation. Later, there is a revenue-sharing system for each party in cooperation with the agreed tenor [22]. This is a commitment to the use of sharia systems on sharia P2P Lending Fintech as it happens when the Italians are using sharia Crowdfunding fintech: "The Sharī ' A-compliant Crowdfunding invests in halal socially responsible projects/products, shares The risks of The investment, and its characterized by the absence of an interest rate." [23].

Fatwa, according to language, means the answer to an event, while the understanding of Fatwa according to syara' is to explain the ruling of syara' in a question as an answer to a question, whether the questioner is a clear identity or not, both individual and collective [24]. Fatwa is the official answer to questions and issues related to legal matters. Fatwa is derived from the Arabic word al ifta', al-fatwa, which means decision making. Fatwas are not a legal decision that is made easily or so-called lawmaking without basis [25]

According to Prof Amir Syarifuddin, Fatwa or ifta' comes from the word afta, which means to explain. Definitively, the Fatwa attempts to explain the ruling of shaa' by its experts to people who do not know it [26]. From the above understanding, the Fatwa is the result of ijtihad a mufti connected with the legal events presented to him. So fatwas are more specific than fiqh or ijtihad in general. Because it may be a fatwa issued by a mufti, it has been formulated in jurisprudence, only not understood by the fatwa requester.

Fatwa has a very important position in Islamic law, so the Fatwa, according to the view of the scholars, is optional "ikhtiyariah" (a choice that is not legally binding, although the moral bind to Mustafa (the party requesting the Fatwa), is for other than the Mustafti is "I'lâniyah" or informative which is more than just discourse. They are open to taking the same Fatwa or requesting a fatwa to Mufti/another member.

As for his position in the Islamic legal system, the current Fatwa results from the collective Ijtihâd. However, it cannot be likened to Ijma ', because the scholars who have a role in the collective Ijtihâd does not cover all the scholars who are the requirements for an ijmâ, 'because of the activities of the Jama'i ijtihâd (collective ijtihâd ). It is possible to do several times by different actors simultaneously and place, so the ruling 
results are possible. There is a difference between a single activity ijtihâd Jama'i (collective Ijtihâd) with others, despite the same problems. However, Ijmâ ' does not allow different opinions because all scholars have agreed that the Fatwa is not an ijmâ, 'and It is possible for the public to accept or not a fatwa [29].

While its position in Indonesia's positive legal system is that based on the legal source in the national legal source, consisting of laws, customs, court judgments (Jurisprudence), treaties (Interstate agreements), doctrines (opinions of Experts/jurists), and based on article 7 paragraph (1) UU. No. 12 the Year 2011 concerning the establishment of legislation mentioned that the type and hierarchy of the legislation consist of: the Constitution of the Republic of Indonesia year 1945; Provision of the People's Consultative Assembly; Legislation/Government regulations instead of laws; Government regulations; Presidential regulation; Provincial regulations; District/city regulations. Based on the above, the Fatwa has no position in the source of positive Indonesian law or law No. 12 The year 2011 on legislation. The Fatwa is merely an opinion, the advice of the scholars who are not binding and to be valid binding. The Fatwa must pass the legislation in advance, which then become a law [29]. However, based on the introduction of legal science, always include opinions (doctrines), including in this case the fatwas of scholars in MUI, as one of the sources of law in addition to other legal sources such as legislation, judicial decisions, and international treaties [30].

Notwithstanding the regulation of the Financial Services Authority (POJK) No. 77/POJK. 01/2016 On lending services borrowed money-based information technology exists in the hierarchy which is legally binding in general both conventional P2P lending fintech as well as Sharia $\mathrm{p} 2 \mathrm{p}$ lending Fintech but the position of the Fatwa Council of National Sharia Indonesian Ulama (DSN MUI) Number 117 the year 2018 about financing services based information technology based on the principle of sharia that does not constitute a type of legislation that has a general binding strength is precisely applied and binding on the sharia P2P Lending Fintech, In this case, ignore the POJK Article 19 paragraph (2) Letter $\mathrm{F}$ and prefer Fatwa MUI on the fourth decision of the number (1).

\section{The Greatest Happiness of the Greatest Number}

Bentham argues that natural human beings live in two strengths, namely pain, and pleasure: "Nature has placed humanity under the governance of two sovereign Masters, pain and pleasure. It is for them alone to point out what we ought to do and determine what we shall do. On the one hand, the standard of right and wrong, on the other the chain of causes and effects, are fastened to their throne " [31].

The theory of utilitarianism that is put forward based on happiness or pleasure as much as possible for as many people as possible gives a view of pleasure through various sources of pleasure itself, on one which is pleasure because of righteousness, which is a feeling of pleasure because of the belief to obtain mercy from God [10] :

Bentham makes a catalog of the simple pleasures of godliness. He thinks the pleasure that accompanies the belief to obtain God's grace. Consequently, it has the power to expect help from the Lord in this life and other lives [10]. In addition to the pleasure catalog, Bentham also made catalogs of suffering among the suffering of righteousness. According to this, suffering comes from fear of wrongdoing to the Almighty and fear of punishment in this life or the life to come. If deemed reasonably unfounded, this suffering is referred to as a religious fear [10]. This is appropriate to illustrate Fintech P2P Lending Syariah users, namely they feel safe and happy when using the Fintech P2P Lending Syariah financial system which refers to beliefs in their religious teachings (Muslims) and they have suffering and fear when they violate it.

Bentham's legal objectives consist of: a living source; Prosperity, Equality Sense of security. Of all these purposes, only a sense of security that is always reaching out to the future, livelihood, prosperity, and equality is only associated with a time of the day. Still, the sense of security can reach the future in terms of all the goodness that can be felt to put a sense of security as the ultimate goal [10].

This seems appropriate to illustrate the usage of the Sharia P2P Lending Fintech that the related parties feel safe and happy when using the financial system Fintech P2P lending Sharia which refers to the belief in the teachings of religion (Muslims) and they have religious suffering and fear when they break it. The use of the sharia system as a realization of the common good is a form of justice, not merely the interests of individuals but also society's interests.

3. Implementation of Sharia Economic Law in Indonesia

The number of Indonesian Muslims who reach $87 \%$ of Indonesia's total population and the religious Nature of Indonesia to the economic law of Sharia in Indonesia has a very strong foundation. The provisions of article 29 paragraph (1) Constitution 1945 expressly states that the State, based on the almighty Godhead, essentially contains three meanings, namely:

a. The State must not make legislation or conduct policies contrary to the foundation of faith in the Almighty God;

b. The State is obliged to make legislation or conduct policies for the implementation of a sense of faith in the Almighty God of the religious believers who need it;

c. The State is obliged to create laws that prohibit anyone from harassing religious teachings (atheism).

Article 29, sentence (2) Constitution 1945 mentioned that the State guarantees each population's independence to embrace their religion and worship according to its religion and belief. The word "warrant" as defined in article 29 paragraph (2) of the Constitution 1945 is 
"imperatives," meaning that the State is actively obliged to make efforts for each population to embrace religion and worship according to its religion and belief. In fact, through the provisions of article 29 paragraph (2) Constitution 1945, all Islamic Sharia, especially those about the areas of the law of transaction, can essentially be executed legally and formally by the Muslims, either directly or indirectly, with the roads adopted in the positive national law [25]. Although with the Fatwa of MUI community got the benefit of a sense of security and pleasure in running the financial system of Fintech P2P Lending, but the State is obliged to enter the rules by the provisions of the legislation to the financial system of Fintech P2P Lending Sharia has a binding legal force as has long been done by conventional Sharia financial system.

\section{CONCLUSION}

The Indonesian Sharia P2P Lending Fintech Agreement does not use POJK No. 77/POJK. 01/2016, which requires the inclusion of loan interest rates as of Article 19 paragraph (2) letter F, but still uses Sharia principle as Fatwa DSN MUI No. 117 the year 2018. The same is done by other countries that use Shariah principles in financial technology. Fintech arrangement P2P Sharia Lending can run well by using DSN MUI Fatwa No. 117 of 2018. pleasure comes from truth, by using Fintech P2P Sharia Lending providers, organizers, and beneficiaries feel secure as the purpose of the law reaches into the future. These benefits provide justice that meets the interests of the individual and the interests of Indonesian Muslims. However, the Fatwa is not binding; therefor it must be regulated in a regulation that complies with Article 7 paragraph (1) of the Law. 12 of 2011 concerning the Establishment of Legislation so as to provide legal certainty for the parties.

\section{REFERENCES}

[1] Otoritas.Jasa.Keuangan, "Survei Nasional Literasi dan Inklusi Keuangan 2019," ojk.go.id, 2020. https://www.ojk.go.id/id/berita-dan-

kegiatan/publikasi/Pages/Survei-Nasional-Literasidan-Inklusi-Keuangan-2019.aspx.

[2] N. Nemoto, B. Huang, and D. J. Storey, "Optimal Regulation of P2P Lending for Small and MediumSized Enterprises," SSRN Electron. J., no. 912, 2019, doi: 10.2139/ssrn.3313999.

[3] P. R. Center, "Muslim Population by Country," globalreligiousfutures.org, 2010. globalreligiousfutures.org/religions/muslims.

[4] F. A. Burhan, "Pasar Fintech Syariah RI Terbesar ke-5 Dunia, Banyak Pengguna Milenial," Katadata.co.id, 2021. https://katadata.co.id/desysetyowati/digital/60938af1 8196a/pasar-fintech-syariah-ri-terbesar-ke-5-duniabanyak-pengguna-milenial.

[5] V. B. Kusnandar, "Indonesia, Negara dengan Penduduk Muslim Terbesar Dunia," katadata.co.id,
2019.

https://databoks.katadata.co.id/datapublish/2019/09/ 25/indonesia-negara-dengan-penduduk-muslimterbesar-dunia.

[6] L. Puspaningtyas, "Fintech Syariah Tumbuh Subur di Malaysia, Singapura, dan RI," republika.co.id, 2020.

https://republika.co.id/berita/q79j6d383/emfinteche m-syariah-tumbuh-subur-di-malaysia-singapura-danri.

[7] R. U. Al-Hashfi and A. S. Zusryn, "Exploring Islamic Peer-To-Peer Lending for the Unbankable," Airlangga Int. J. Islam. Econ. Financ., vol. 2, no. 2, p. 71, 2020, doi: 10.20473/aijief.v2i2.20648.

[8] E. Ildarovna Bulatova, E. Alekseevna Potapova, R. Andreevna Fathutdinova, and R. Chirgishanovich Yandiev, "The fintech and islamic finance synthesis in the modern world," 3C TIC Cuad. Desarro. Apl. a las TIC, no. October, pp. 258-273, 2019, doi: 10.17993/3ctic.2019.83-2.258-273.

[9] H. Alaydrus, "Pemerintah Luncurkan Peta Jalan Ekonomi Syariah 2019-2024," Bisnis.com, 2019. https://ekonomi.bisnis.com/read/20190514/9/922404 /pemerintah-luncurkan-peta-jalan-ekonomi-syariah2019-2024.

[10] J. Bentham, The Theory of Legislation, 5th ed. Bandung: Nuansa Cendekia, 2019.

[11] DSN-MUI, "Fatwa Dewan Syariah Nasional-Majelis Ulama Indonesia No: 117/DSN-MUI/II/2018 Tentang Layanan Pembiayaan Berbasis Teknologi Informasi Berdasarkan Prinsip Syariah,”p. 14, 2018.

[12] rustamaji muhammad Sulistiyono, Adi, Hukum Ekonomi Sebagai Panglima, 1st ed. sidoarjo: masmedia buana pustaka, 2009.

[13] R. A. Dewantari et al., "Penerapan teori efisiensi dalam pedekatan," vol. VI, no. 2, pp. 277-281, 2018.

[14] CNN, "Penyaluran Pinjol Tembus Rp221,56 T per Juni 2021," cnnindonesia.com, 2021. https://www.cnnindonesia.com/ekonomi/202107301 92656-92-674517/penyaluran-pinjol-tembusrp22156-t-per-juni-2021.

[15] Otoritas.Jasa.Keuangan, "Statistik Fintech Lending Periode Juni 2021," ojk.go.id, 2021. https://www.ojk.go.id/id/kanal/iknb/data-danstatistik/fintech/Pages/Statistik-Fintech-LendingPeriode-juni-2021.aspx.

[16] "Asosiasi Fintech Syariah Indonesia," AFSI. https://fintechsyariah.id/id.

[17] Otoritas.Jasa.Keuangan, "Perusahaan Fintech Lending Berizin dan Terdaftar di OJK," ojk.go.id, 2021. https://www.ojk.go.id/id/kanal/iknb/financialtechnology/Documents/Penyelenggara Fintech Lending Terdaftar dan Berizin di OJK per 27 Juli 2021.pdf.

[18] AFPI, "Asosiasi Fintech Pendaaan Bersama Indonesia (AFPI)," AFPI. https://www.afpi.or.id/members/page/3.

[19] S. R. Sjahdeini, Perbankan Syariah: Produk-produk dan Aspek-aspek Hukumnya. Jakarta: Kencana, 2018. 
[20] M. S. M. A. Shawi, Problematika Investasi Pada Bank Islam: Solusi Ekonomi Islam. Jakarta: migunani, 2008.

[21] A. A. M. Azzam, Fiqh Muamalat: Sistem Transaksi Dalam Fiqh Islam. Jakarta, 2014.

[22] M. J. Rizki, "Yuk, Mengenal Aturan Main Fintech Syariah," hukumonline.com, 2020. https://www.hukumonline.com/berita/baca/lt5e1e 0a7 7362a8/yuk--mengenal-aturan-main-fintech-syariah.

[23] P. Pietro Biancone and S. Secinaro, "The equity crowdfunding italy: a model sharia compliant," equity crowdfunding italy a Model sharia compliant, no. 5, pp. 1-10, 2016, doi: 10.13135/24212172/1797.

[24] Y. al- Qardhawi;, A. Yasin;, and Subhan., Fatwa antara ketelitian dan kecerobohan, 1st ed. Jakarta: Gema Insani Press, 1997.

[25] Ahyar A. Gayo, "Laporan Akhir Penelitian Hukum Tentang Kedudukan Fatwa Mui Dalam Upaya Mendorong Pelaksanaan Ekonomi Syariah," bphn.go.id, 2011. http://bphn.go.id/data/documents/kedudukan_fatwa_ mui_dalam_upaya_mendorong_pelaksanaan_ekono mi_syariah.pdf.

[26] Mardani, Ushul Fiqh. Jakarta: RajaGrafindo Persada, 2013.

[27] S. A. Syakir, Mukhtashar Tafsir Ibnu Katsir Jilid 4. Jakarta: Darus Sunnah Press, 2016.

[28] M. Hamidy, Terjemahan Nailul Authar :Himpunan Hadis-hadis Hukum Jilid 6. Surabaya: Bina Ilmu, 1993.

[29] M. Erfan Riadi, "Kedudukan Fatwa Ditinjau Dari Hukum Islam Dan Hukum Positif," Ulumuddin, vol. 6, no. 4, pp. 468-477, 2010.

[30] D. Indrayana, "Fatwa MUI, Hukum Positif, dan Hukum Aspiratif," nasional.kompas.com, 2016. https://nasional.kompas.com/read/2016/12/22/17262 341/fatwa-mui-hukum-positif-dan-hukum-aspiratif?

[31] A. Latipulhayat, "Khazanah: Jeremy bentham," Ilmu Huk., vol. 2, no. 2, pp. 413-425 (p.424), 2015, [Online]. http://jurnal.unpad.ac.id/pjih/article/download/7342/ 3375. 